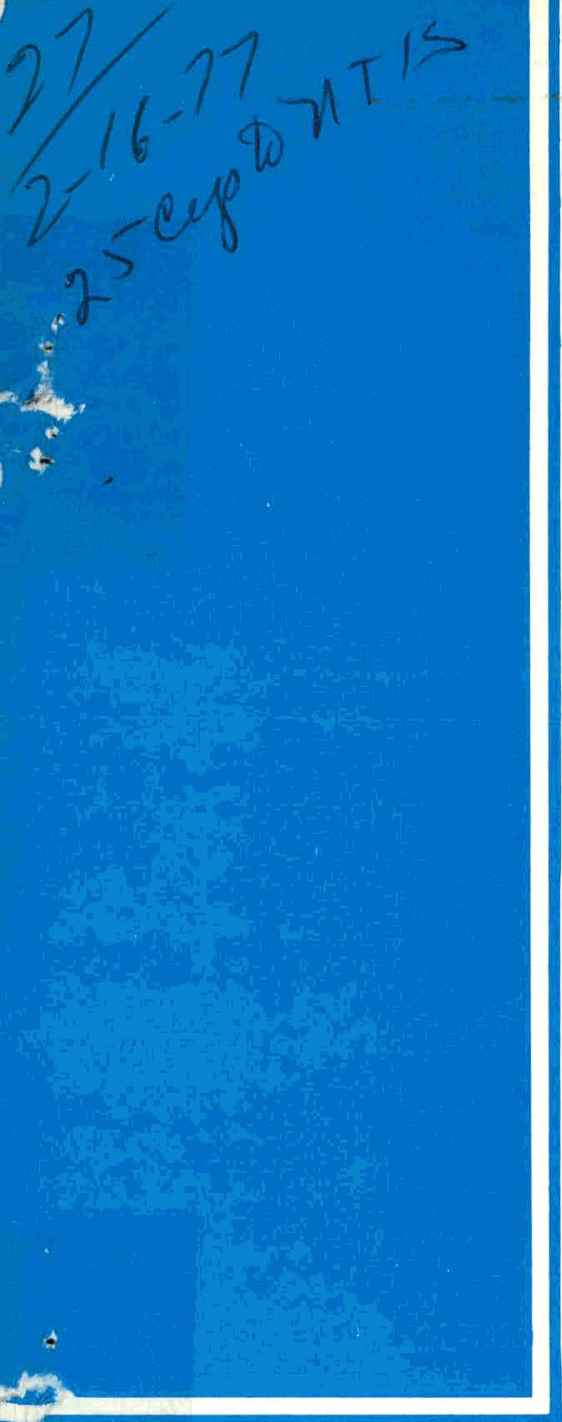

\title{
Coal Technology Program Progress Report for December 1976
}

\section{OAK RIDGE NATIONAL LABORATORY}




\section{DISCLAIMER}

This report was prepared as an account of work sponsored by an agency of the United States Government. Neither the United States Government nor any agency Thereof, nor any of their employees, makes any warranty, express or implied, or assumes any legal liability or responsibility for the accuracy, completeness, or usefulness of any information, apparatus, product, or process disclosed, or represents that its use would not infringe privately owned rights. Reference herein to any specific commercial product, process, or service by trade name, trademark, manufacturer, or otherwise does not necessarily constitute or imply its endorsement, recommendation, or favoring by the United States Government or any agency thereof. The views and opinions of authors expressed herein do not necessarily state or reflect those of the United States Government or any agency thereof. 


\section{DISCLAIMER}

Portions of this document may be illegible in electronic image products. Images are produced from the best available original document. 
Printed in the United States of America. Available from National Technical Information Service

U.S. Department of Commerce

5285 Port Royal Road, Springfield, Virginia 22161

Price: Printed Copy $\$ 4.00$; Microfiche $\$ 3.00$

This report was prepared as an account of work sponsored by the United States Government. Neither the United States nor the Energy Research and Development Administration/United States Nuclear Regulatory Commission, nor any of their employees, nor any of their contractors, subcontractors, or their employees, makes any warranty, express or implied, or assumes any legal liability or responsibility for the accuracy, completeness or usefulness of any information, apparatus, product or process disclosed, or represents that its use would not infringe privately owned rights. 
Contract No. W-7405-eng-26

COAL TECHNOLOGY PROGRAM

PROGRESS REPORT FOR DECEMBER 1976

Date Published - February 1977

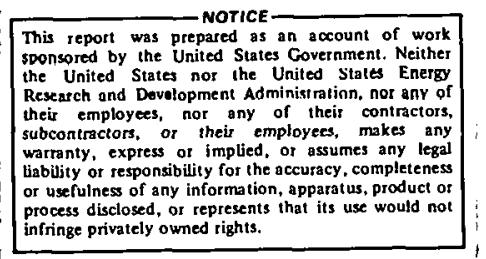

NOTICE This document contains information of a preliminary nature. It is subject to revision or correction and therefore does not represent a final report.

\author{
OAK RIDGE NATIONAL LABORATORY \\ Oak Ridge, Tennessee 37830 \\ operated by \\ UNION CARBIDE CORPORATION \\ for the \\ ENERGY RESEARCH AND DEVELOPMENT ADMINISTRATION
}


ORNL/TM-5044, Progress Report for August 1974

ORNL/TM-5045, Progress Report for September 1974

ORNL/TM-5046, Progress Report for October 1974

ORNL/TM-4787, Progress Report for November 1974

ORNL/TM-4796, Progress Report for December 1974

ORNL/TM-4850, Progress Report for January 1975

ORNL/TM-4873, Progress Report for February 1975

ORNL/TM-4892, Progress Report for March 1975

ORNL/TM-4946, Progress Report for Apr11 1975

ORNL/TM-4966, Progress Report for May 1975

ORNL/TM-5010, Progress Report for June 1975

ORNL/TM-5037, Progréss Keport for July 1975

ORNī/TM-5092, Progress Report for August 1975

ORNL/TM-5124, Progress Report for September 1975

ORNL/TM-5186, Progress Report for October 1975

ORNL/TM-5214, Progress Report for November 1975

ORNL/TM-5246, Progress Report for December 1975

ORNL/TM-5301, Progress Report for January 1976

ORNL/TM-5321, Progress Report for February 1976

ORNL/TM-5430, Progress Report for March 1976

ORNL/TM-5479, Progress Report for Apr11 1976

ORNL/TM-5532, Progress Report for May 1976

ORNL/TM-5595, Progress Report for June 1976

ORNL/TM-5611, Progress Report for July 1976

ORNL/TM-5654, Progress Report for August 1976

ORNL/TM-5674, Progress Report for September 1976

ORNL/TM-5717, Progress Report for October 1976

ORNL/TM-5752, Progress Report for November 1976 


\section{CONTENTS}

$\underline{\text { Page }}$

Abstract . . . . . . . . . . . . . . . . . . . . 1

1. Summary . . . . . . . . . . . . . . . . . . . 1

2. Coal Conversion Process Development . . . . . . . . . . . 3

2.1 Hydrocarbonization Research . . . . . . . . . . . 3

2.2 Residue Carbonization . . . . . . . . . . . . . 6

2.3 Experimental Engineering Support of an In Situ

Gasification Process . . . . . . . . . . . . . . 7

2.4 Coal-Solvent-Hydrogen Mixing . . . . . . . . . . . . . . 7

2.5 Pressurized Carbonization of Consol Synthetic

Fuel Solid Residues . . . . . . . . . . . . . . . . . . . 8

2.6 References for Section 2 . . . . . . . . . . . . . . 8

3. Materials Engineering . . . . . . . . . . . . . . . . . 9

3.1 Pressure Vessel and Piping Technology Assessment . . . . 9

3.2 Inspection Techniques for Wear- and ProcessResistant Coatings . . . . . . . . . . . . . . 10

3.3 Iron and Nickel Carbonyl Formation and Prevention . ... . 11

3.4 Development of Techniques for Welding and Cladding C.r-Mo and Low-Alloy Steels . . . . . . . . . . . 11

3.5 Prestressed Concrete Pressure Vessel Studies . . . . . . 12

3.0 Pluidized Bcd Combuetion . . . . . . . . . . . . . . . . 14

3.7 Failure Analysis and Prevention . . . . . . . . . . . 14

1. Alkali Metal Vapọ Topping Cycles . . . . . . . . . . . 15

4.1 Potassium Vapor Topping Cycle . . . . . . . . . . . 15

4.2 Coal-Fired Alkali Metal . . . . . . . . . . . . . 17

5. Critical Components Test Facility . . . . . . . . . . . . . 21

6. Engineering Studies and Technical Support . . . . . . . . . . 22

6.1 Process Modeling Support . . . . . . . . . . . . . . 22

6.2 Process Research Digest . . . . . . . . . . . . . . . 23

6.3 Survey of Industrial Equipment Capabilities . . . . . . . 23

6.4 Large Air Separation Plant Study . . . . . . . . . . . 25 
Page

7. Process and Program Assistance . . . . . . . . . . . 26

7.1 Low-Btu Coal Gasification . . . . . . . . . . . 26

7.2 Direct Combustion . . . . . . . . . . . . . . 27

7.3 Advanced Power Conversion Systems . . . . . . . . . . 27

7.4 Liquefaction . . . . . . . . . . . . . . . 27

7.5 In Situ Coal Gasification . . . . . . . . . . . . 27

7.6 Coal Beneficiation .. . . . . . . . . . . . . 28

7.7 Gas Cleanup sludles. . . . . . . . . . . . . . 28

7.8 Coal Prices and Volumes and Transportation Costs . . . . : 29

7.y The Potentlai for Synthesis of Chemicals from Coal . . . . 29

8. Fossil Energy Environmental Project . . . . . . . . . . . 30

8.1 Program Plan . . . . . . . . . . . . . . . 30

8.2 Environmental Inclusions in RFPs ............ . 30

8.3 Landfill Storage of Solid Wastes . . . . . . . . . . 30

8.4 Environmental Monitoring Handbook . . . . . . . . . . 30

8.5 Programmatic EIS-P1peline Gas . . . . . . . . . . . . 30

9. Coal-Fueled MIUS . . . . . . . . . . . . . . . . . 31

9.1 Program Status . . . . . . . . . . . . . . . . 31

9.2 Coal Metering and Feed Systems . . . . . . . . . . . . 31

9.3 Supplemental Studies . . . . . . . . . . . . . 31 
COAL TECHNOLOGY PROGRAM PROGRESS REPORT FOR DECEMBER 1976

ABSTRACT

This report - the twenty-ninth of a series - is a compendium of monthly progress reports for the ORNL research and development programs that are in support of the increased utilization of coal as a source of clean energy. The projects reported this month include those for coal conversion process development, materials engineering, alkali metal vapor topping cycles, a critical components test facility, engineering and support studies, process and program assistance, environmental assessment studies, and coal-fueled MIUS.

\section{SUMMARY}

J. P. Nichols

Highlights of our progress in December are as follows:

- In each of three residue carbonization experiments this month, operation was sustained for 2 to $21 / 2 \mathrm{hr}$, and 10 to $101 / 2 \mathrm{lb}$ of feed mixture was carbonized (four parts char to one part H-Coal vacuum still bottoms).

- We completed the compilation of material balance results for run HC-9 in our hydrocarbonization bench-scale system. Work is resuming on the ambient model studies of the recirculating fluidized bed.

- In our coal/solvent/hydrogen mixing work, the cause of problems with pulse testing techniques have been found and apparently corrected. A reference in the Iiterature has been found which indicates that highly turbulent flow does increase the rate of hydroliquefaction reactions.

- Fabrication of major equipment items is nearly complete for our studies of pressurized carbonization of Consol synthetic fuel solid residues. Installation of this equipment in Bldg. 3541 will begin shortly.

- We completed and submitted for ERDA review a final draft of the report, Assessment of Materials Technology of pressure Vessels and Piping for Coal Conversion. Experimental work to determine toughness behavior of thick sections of ferritic and low-alloy steels is being initiated.

- Several methods for evaluating wear-resistant coatings are being investigated, and in-house facilities are being used to make coated specimens. 
- Work was initlated on the deposition of protective claddings (Alloy 20) with high integrity.

The experimental program for determining rates of iron and nickel carbonyl formation with low-alloy steel in the presence of synthesis gas is being terminated.

- Design studies of prestressed concrete pressure vessels for coal conversion plants were continued.

- Evaluations of materials from pilot plants to build an experience backlog for prevention of fallures and analysis of fallures is in progress.

- In our gas-fired potassium boller work, we continued testing of the. boiler module with water, as well as the design and fabrication of components that will be necessary for tests with potassium.

- In our coal-fired alkali metal vapor topping cycle work, we completed parametric cycle analyses and conceptual turbine design studies for systems utilizing cesium and potassium.

- Work is proceeding on schedule for the completion of our conceptual design study of a nonsite-specific Critical Components Test Facility by January $31,1977$.

- In our project for engineering studies and technical support, we continued process modeling studies, the preparation of a first Process Research Digest, and surveys of industrial equipment capabilities.

- Our process and program assistance program continued with work on low-Btu gasification, direct combustion, advanced power conversion systems, In situ coal gasification, and coal beneficlation. Subcontracts were signed with Ralph M. Parsons, Inc., and Radian Corporation, respectively, for parallel studies on liquefaction and synthesis of chemicals from coal.

- In our Fossil Energy Environmental Project, we submitted our report, entitled "Environmental Inclusions in Requests for Proposals," completed a literature search and defined a project to study the landfill storage of solid wastes, and began the preparation of an environmental monitoring handbook and a programmatic environmental impact statement for the pipeline gas program.

- Design work on the coal-fueled MIUS experimental unit remained suspended during the work pending decisions of program defintition. We continued corrosion tests and tests of the coal feeding system. 


\section{COAL CONVERSION PROCESS DEVELOPMENT}

J. R. Hightower, Jr.

Coal conversion process development activities are carried out in the Chemical Technology Division. This section discusses hydrocarbonization studies in a 20-atm bench-scale facility, studies of residue carbonization in an atmospheric pressure carbonizer and in a pressurized carbonizer, engineering support studies for in situ gasification, and studies for identifying and characterizing alternate reactor concepts for coal hydroliquefaction.

\subsection{Hydrocarbonization Research}

H. D. Cochran, Jr.

\subsubsection{Experimental Development (C. H. Brown, Jr., and J. Beams)}

During January work will resume on the ambient mockup of the recirculating fluidized bed. The primary emphasis of this effort will be analysis of previously obtained data and mathematical modeling of the system. Work has also begun on an improved method of measuring bed recirculation rates by following a radioactively tagged particle in the moving bed.

2.1.2 Bench-Scale System (P. R. Westmoreland, C. H. Brown, Jr., G. E. Oswald, J. Beams, J. C. Rose, and L. S. Dickerson)

Fabrication and Installation. A ground-fault interrupt system was installed on the electric resistance heaters on the experiment equipment to indicate short circuits to ground and to protect the system from such failures.

Operation. Preliminary data analyses for run HC-9 are included in Tables 2.1 and 2.2. Effluent gas analysis data for run HC-9 were reported in the November 1976 monthly report. As shown in Table 2.2, closure of the overall mass balance was poor due to the influx of water from the scrubber pump seal pot into, the scrubber water reservoir.

Operation of the bench-scale hydrocarbonizer has been impaired because of recurrent problems with the seals on the Corcoran centrifugal pump used to recirculate scrubber liquid. The seals were originally damaged by erosion from char which was blown over into the scrubber from the reactor during an emergency purge of the system. Duplicate sets of replacement seals were ordered from the vendor. In the interim, the existing seals were refaced and have been used since September. The replacement seals, due from the vendor in November, have been rescheduled for shipment in January. 
Tajle 2.1 Preliminary material balance for Experiment HC-9

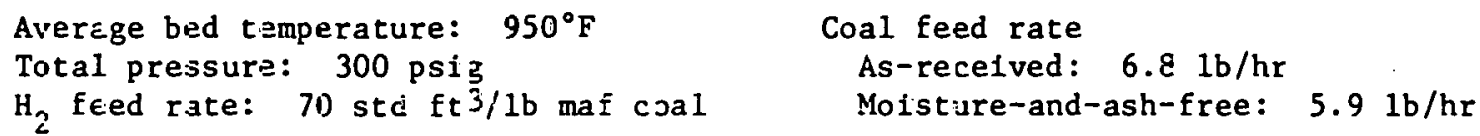

\begin{tabular}{|c|c|c|c|c|c|c|c|c|}
\hline & & $\begin{array}{l}\text { Mass } \\
(\mathrm{g})\end{array}$ & $\begin{aligned} & \text { Carbon } \\
& \text { Eraction }\end{aligned}$ & $\begin{array}{c}\text { Ash } \\
\text { fraction }\end{array}$ & $\begin{array}{l}\text { Sulfur } \\
\text { fraction }\end{array}$ & $\begin{array}{l}\text { Percent of } \\
\text { carbon fed }\end{array}$ & $\begin{array}{l}\text { Percent of } \\
\text { ash fed }\end{array}$ & $\begin{array}{l}\text { Percent of } \\
\text { sulfur fed }\end{array}$ \\
\hline \multicolumn{9}{|c|}{ Input. } \\
\hline $\begin{array}{l}1 . \\
2 .\end{array}$ & $\begin{array}{l}\text { Coal } \\
\text { Scrubjer water }\end{array}$ & $\begin{array}{l}14,670 \\
20,000\end{array}$ & $\begin{array}{l}0.6342 \\
0\end{array}$ & $\begin{array}{l}0.0657 \\
0\end{array}$ & $\begin{array}{l}0.0042 \\
0\end{array}$ & $\begin{array}{c}100.0 \\
0\end{array}$ & $\begin{array}{c}100.0 \\
0\end{array}$ & $\begin{array}{c}100.0 \\
0\end{array}$ \\
\hline \multicolumn{9}{|c|}{ Output } \\
\hline & $\begin{array}{l}\text { Char recovered } \\
\text { Scrubber top phase } \\
\text { Scrubber middle } \\
\text { (aqueous) phase }\end{array}$ & $\begin{array}{r}5,346 \\
0 \\
34,815\end{array}$ & $\begin{array}{l}0.8138 \\
0 \\
0.00364\end{array}$ & $\begin{array}{l}0.1142 \\
0 \\
0\end{array}$ & $\begin{array}{l}0.00315 \\
0 \\
0\end{array}$ & $\begin{array}{l}46.8 \\
0 \\
1.36\end{array}$ & $\begin{array}{c}63.3 \\
0 \\
0\end{array}$ & $\begin{array}{c}27.3 \\
0 \\
0\end{array}$ \\
\hline $\begin{array}{l}6 . \\
7 . \\
8 .\end{array}$ & $\begin{array}{l}\text { Scrubber bottom phese } \\
\text { Cold trap top pt.ase } \\
\text { Cold trap middle. } \\
\text { (aqueous) phase }\end{array}$ & $\begin{array}{r}3,7<2 \\
0 \\
2,8<0\end{array}$ & $\begin{array}{l}0.3824 \\
0 \\
0.00413\end{array}$ & $\begin{array}{l}0.0497 \\
0\end{array}$ & $\begin{array}{l}0.00186 \\
0\end{array}$ & $\begin{array}{l}15.4 \\
0 \\
0.12\end{array}$ & $\begin{array}{c}19.3 \\
0 \\
0\end{array}$ & $\begin{array}{c}11.3 \\
0 \\
0\end{array}$ \\
\hline $\begin{array}{l}9 . \\
10 \\
11\end{array}$ & $\begin{array}{l}\text { Cold =rap bottom phase } \\
\text { Miscellaneous tars } \\
\text { Gases }\end{array}$ & $\begin{array}{r}2 \in 9.8 \\
\subsetneq 8.3 \\
3,8 \& 5\end{array}$ & $\begin{array}{l}0.4610 \\
0.657 \\
--\end{array}$ & $\begin{array}{l}0.0567 \\
0.0086 \\
0\end{array}$ & $\begin{array}{l}0.00208 \\
0.0016 \\
--\end{array}$ & $\begin{array}{r}1.34 \\
0.69 \\
10.24\end{array}$ & $\begin{array}{l}1.59 \\
0.09 \\
0\end{array}$ & $\begin{array}{l}0.90 \\
0.26 \\
58^{\mathrm{a}}\end{array}$ \\
\hline \multicolumn{9}{|c|}{$\underline{\text { Rinses }}$} \\
\hline $\begin{array}{l}12 . \\
13 .\end{array}$ & $\begin{array}{l}\text { Scrubber - water } \\
\text { Scrubber and cold trap - } \\
\text { perchloroethylene }\end{array}$ & $\begin{array}{l}34,840 \\
53,250\end{array}$ & $\begin{array}{l}0.010049 \\
0.00542\end{array}$ & $\begin{array}{l}0 \\
0.000477\end{array}$ & $\begin{array}{l}0 \\
0.000029\end{array}$ & $\begin{array}{l}0.18 \\
3.11\end{array}$ & $\begin{array}{l}0 \\
2.64\end{array}$ & $\begin{array}{l}0 \\
2.6\end{array}$ \\
\hline Over & all balances & $147 \%^{\mathrm{b}}$ & & & & 79.2 & 86.9 & 100.0 \\
\hline
\end{tabular}

${ }^{\mathrm{a}}$ Calculated by difference.

${ }^{b}$ Includes influx of water Erom serubber pump seal into scrubber water. 
Table 2.2 Summary of preliminary material balances for Experiment $\mathrm{HC}-9$

\begin{tabular}{lc}
\hline \multicolumn{1}{c}{ Experiment } & HC-9 \\
\hline Average bed temperature, ${ }^{\circ} \mathrm{F}$ & 950 \\
Reactor pressure, psig & 300 \\
Carbon balance (\% of carbon fed) & \\
Char & 54.3 \\
Liquids & 4.6 \\
Overall & 10.2 \\
& 79.2 \\
Overall ash balance (\% of ash fed) & 86.9 \\
Sulfur balance (\% of sulfur fed) & \\
Char & 37.9 \\
Liquids & 4.5 \\
Gases & $58^{\mathrm{a}}$ \\
Overall mass balance. (\%) & $147^{\mathrm{b}}$ \\
\hline
\end{tabular}

${ }^{a}$ Calculated by difference from $100 \%$.

${ }^{b}$ Includes influx of water from scrubber pump seal into scrubber water. cApproximate. 
Run HC-10 was delayed due to leakage of the scrubber pump seals. The seals will be resurfaced again, and run HC-10 will be performed in January 1977.

Work Forecast. Routine experimentation will continue in January with a recirculating fluidized-bed run ( $\mathrm{HC}-10)$ at $300 \mathrm{psig}$ and approximately $1050^{\circ} \mathrm{F}$.

\subsection{Residue Carbonization}

H. D. Cochran, Jr.

\subsubsection{Operation (J. B. Gibson, R. L. Andrews, and J. R. Cox)}

There were three residue carbonization runs attempted during December. Al1 three attempts were made with a feed mixture of 4 parts char to 1 part residue and with a methyl-naphthalene scrub liquid. The change from a water scrub liquid was a successful attempt to condense the aerosol seen in RC-19 and to prevent plugging of the string filter.

In run RC-20 10 lbs of feed mixture was fed during the slightly less than 2-hr run. The run was once interrupted by a plugged feed line. During the cleanup after the run the draft tube was discovered to be plugged. Therefore, in $\mathrm{RC}-21$ the gas flows were increased in a successful attempt to prevent this plugging. Also, a small assembly was fabricated and installed at the base of the feed nozzle to facllitate the removal of plugo from the feed line during experiments. This assembly was used successfully during $\mathrm{RC}-21$.

In run $\mathrm{RC}-21,10-1 / 2$ lhs of feed mixture was fed in $2-1 / 4 \mathrm{hr}$. The run was leimlilated by pligg in the reactor-to-scrubber line causing an overpressure shutdown. The part of the reactor-tn-srrubber line which extends into the scrubber had the most extensive buildup; there was some buildup in the exit from the reactor. The extended part of the reactorto-scrubber line was cut flush with the scrubber wall.

In run $\mathrm{RC}-22$ the higher gas flows were maintalned to prevent draft tube plugging. The run was terminated by a plug in the reactor-to-scrubber line after $10-1 / 2$ lbs had been fed in 2-1/2 hr. After this run, the preheater was modified in an effort to increase the gas heating efficiency. The Inslde cross sectional area was reduced to increase the gas velocity and, hence, to increase the heat transfer coefficient.

\section{Work Forecast}

A run to study the agglomerating characteristics of Illinols No. 6 coal will be made. This run will be made with a water scrub liquid. Following this a run will be made with $100 \%$ char in order to completely devolatilize the char before $1 t$ is mixed with residue to form a residue/char feed mixture. 


\subsection{Experimental Engineering Support of an In Situ Gasification Process}

R. C. Forrester III, G. D. Owen, S. M. Gibson, and J. D. Cohili

Two-dimensional pyrolysis studies were continued with the heating of a $4.014-\mathrm{kg}$ block of subbituminous coal to $873^{\circ} \mathrm{K}$ at $0.3 \mathrm{~K} / \mathrm{min}$. Data produced by this test will complete the program analysis of western subbituminous coals at atmospheric pressure under inert gas atmospheres. Equipment changes required to examine pyrolysis reactions under reducing gas atmospheres are being made and those tests will be inftlated early in CY 1977.

Samples of eastern bituminous coals representative of those to be gasified by MERC in their UCG field tests have been recelved and will be prepared for pyrolysis experiments. Initial results are expected within the next three weeks. Ultimately, a comparison of two-dimensional effects upon the pyrolysis of subbituminous and bituminous coals will be made.

\subsection{Coal-Solvent-Hydrogen Mixing}

J. R. Hightower, Jr., and R. C. Lovelace

The objectlve of the work reported here is to demonstrate that a highly turbulent plug flow reactor of novel design would allow adequate hydrodesulfurization and hydroliquefaction without the use of hydrotreating catalysts. The present work plan calls for two phases: (1) simulated contractor studies which have the objective of identifying suitable reactor configurations (we will investigate a reactor consisting of several venturis in series and one with vortex flow similar to a cyclone device) through tests with water/coal slurries and a1r, and (2) hydrogenation verification studies in which coal is hydrogenated in a suitable reactor whose design would be based upon results from the first phase studies.

Problems with the pulse testing technique for measuring residence-time distributions apparently were due to rapid concentration oscillations caused by the bubbles in the inlet and outlet streams from the packed column. Electronic RC filters were installed in the output from the conductivity meters, and they effectively filter these oscillations before the signal is recorded. The resulting tracer pulses now seem entirely satisfactory.

A reference in the literature has been found which indicates that highly turbulent flow does increase the rate of hydroliquefaction reactions as has been postulated in this project. Morgan and Veryard ${ }^{l}$ have hydrogenated coal and coal-tar oils in small-dlameter tubes under highly turbulent conditions. Optimum temperature and pressure were reported to be $480^{\circ} \mathrm{C}$ and 3000 psi. A coal (unspecified), which had had its ash content reduced to $0.8 \%$ (to facilitate pumpling), was slurried in anthracene oil ( 14 wt \% coa1) and $85 \%$ of this material was converted to oil and gas using a residence time of $5 \mathrm{sec}$. These experiments showed that conditions of turbulent flow do increase materially the rate of reaction with hydrogen, the higher the degree of turbulence the greater the effect. 


\subsection{Pressurized Carbonization of Consol Synthetic Fuel Solid Residues}

J. R. Hightower, Jr., J. B. Gibson, and S. M. Gibson

Fluor Engineers and Constructors is designing a plant using the Consol Synthetic Fuel (CSF) process for ERDA in which they are considering pressurized gasification of carbonized hydroclone underflow for hydrogen production. In order to avold lock hoppers, they plan to pressurlze the carbonizer and allow the char simply to overflow from the carbonizer to the gasifier. The hydroclone underflow will be slurried with a recycle oil (some of the donor solvent) and pumped into the carbonizer. The ofl would be vaporized and recovered. Fluor would like to know how much of the recycle ofl would be thermally degraded and what residence times would be required to vaporize the oil from the solids at $900^{\circ} \mathrm{F}$ and 50 and $400 \mathrm{psig.} \mathrm{ORNL} \mathrm{has} \mathrm{been} \mathrm{asked}$ to provide quickly some information on these subjects. An experimental batch pressurized carbonizer using $1 \mathrm{~kg}$ (or less) quantities of hydroclone underflow and recycle oil will be used to estimate the fractional recovery of recycle oil and the fate of any thermally degraded oil.

Fabrication of the major equipment items in this study is almost complete and installation of these items in Bldg. 3541 will start shortly. The required design review by the pressure vessel committee has begun. All remaining equipment and instrumentation is either on order or already on hand.

\subsection{References for Section 2}

1. G. Morgan and J. T. Veryard, "Hydrogenation of Coal and Coa1-Tar Oils Under Turbulent Flow Conditions," Society of Chemiral Indistry Journal 57, 152-162 (1938). 


\section{MATERIALS ENGINEERING}

R. T. King

The materials engineering and associated technology reported here are in support of activities directed by the Materials and Power Generation Branch of the Division of Materials and Exploratory Research. Other related work not funded directly by this division of ERDA/FE is included also.

Summary

Materials research and development programs are aimed at several areas. A review of piping and pressure vessel technology has identified several areas in which future work should be centered. Experimental work to determine toughness behavior of thick sections of ferritic and lowalloy steels for pressure containment is being initiated. Several methods for evaluating coatings are being investigated, and in-house facilities are being used to make experimentally coated specimens. Work has been initiated on the deposition of protective claddings (Alloy 20) with high integrity. An experimental program for evaluation of iron and nickel carbonyl formation by reacting $\mathrm{CO}$ gas mixtures with low alloy steels has been terminated. Samples of coolant tubing exposed in a fluidized bed have been received and a tentative sectioning scheme devised. Design studies of prestressed concrete vessels and liners for coal conversion processes were continued. Evaluations of materials from pilot plants to build an experience backlog for prevention of failures and analysis of failures is in progress. A review of all work in progress was held at ERDA-FE headquarters on December 13.

\subsection{Pressure Vessel and Piping Technology Assessment}

D. A. Canonico, R. H. Cooper, B. E. Foster, R. K. Nanstad G. C. Robinson, and G. M. Slaughter

A review of the piping and pressure vessel needs for coal conversion systems is in progress. The program will identify those areas where additional property data needs are required in order to assure that the pressure boundary components in conversion systems can be designed, fahricated, and operated in a safe and reliable manner.

The draft of the report, Assessment of Materials Technology of Pressure Vessels and Piping for Coal Conversion (ORNL-5238), has been completed. Fifteen (15) copies were delivered to Fossil Energy Research early in December. 


\title{
3.2 Inspection Techniques for Wear- and Process-Resistant Coatings
}

\author{
R. W. McClung and G. W. Scott
}

\subsubsection{Review and Evaluation (G. W. Scott)}

An audio-visual presentation was assembled for the annual review of the coating inspection program by ERDA/FE. The presentation was given by R. W. McClung to W. T. Bakker and T. B. Cox at ERDA/FE, Germantown, MD, on December 13. As requested by W. T. Bakker, we have started preparation of a draft work statement for FY-1977.

\subsubsection{Specimen and Standard Fabrication (D. P. Edmonds and J. D. Hudson)}

A third tensile-crack specimen of $\mathrm{ZrO}_{2}$ on Alloy 800 has been sprayed. The second specimen spalled during tensile stressing and did not produce suitable cracks. Thickness standards of $\mathrm{NiCrAl}$ and $\mathrm{ZrO}_{2}$ over $\mathrm{NiCrAl}$ have been prepared. A thermal defect specimen of $\mathrm{ZrO}_{2}$ over $\mathrm{NiCrAl}$ has been prepared. (See also section 3.2.3)

\subsubsection{Specimen and Standard Fabrication (J. D. Hudson and D. P. Edmonds)}

During this reporting period the Welding and Brazing Lab has continued to concentrate on the preparation of $\mathrm{ZrO}_{2}$ and $\mathrm{NiCrAl}$ plasma spray coating with and without known defects. The following specimens have been prepared.

(a) Thermal defect specimen, $0.254 \mathrm{~mm}$ (0.010 in.) thick $\mathrm{ZrO}_{2}$ coating on Incoloy 800 with known defect - $3.175 \mathrm{~mm}$ ( $0.125 \mathrm{in.}$ ) diam disc of mica.

(b) Tensile crack specimens, $0.254 \mathrm{~mm}$ ( 0.010 in.) thick $\mathrm{ZrO}_{2}$ coatings on Incoloy 800.

(c) 'l'hickness standard, $0.076 \mathrm{~mm}$ ( 0.003 in.) thick NiCrAl coating on Incoloy 800 .

(d) Double layer specimen, $0.076 \mathrm{~mm}(0.003 \mathrm{in.}$ ) thick NiCrAd hond layer with $0.178 \mathrm{~mm}(0.007 \mathrm{in.})$ thick $\mathrm{ZrO}_{2}$ layer on Incoloy 800 .

(e) Thermail defect specimen, $0.076 \mathrm{~mm}$ ( $0.003 \mathrm{in.)}$ thick NiCrAl bond layer.with $0.178 \mathrm{~mm}(0.007 \mathrm{in.})$ thick $\mathrm{ZrO}_{2}$ layer on Incoloy 800 with known defect between layers - $3.175 \mathrm{~mm}(0.125 \mathrm{in.})$ diam disc of mica.

(t) Thickness standard, $0.076 \mathrm{~mm}$ ( 0.003 in.) thick NiCrAl bond layer with $0.178 \mathrm{~mm}(0.007 \mathrm{in.})$ thick $\mathrm{ZrO}_{2}$ layer on Incoloy 800 .

\subsubsection{Penetrating Radiation (G. W. Scott)}

The contract and purchase order for our $x$-ray fluorescence system has been awarded to Ortec, Inc. They have notified us that the system will be ready for acceptance testing at the Seller's plant early in January 1977 . 


\subsubsection{Eddy Current (G. W. Scott and C. V. Dodd)}

The through-transmission measurement and computation technique described in earlier reports was tested on aluminum shims of known conductivity at $\mathrm{l} \mathrm{kHz}$ to verify its validity. Check out and programing of the lift-off and conductivity instrument for dielectric coatings continued.

\subsubsection{Surface Inspection Materials (S. D. Snyder)}

We have received two new $\mathrm{ZrO}_{2}$ sciated (0.010-in.-thick coating) tensile crack sfecimens. One of these specimens was tensile stressed to a load of $4000 \mathrm{lb}$. The coating cracked in the dogbone section of the specimen but spalled away from the base metal during the cleaning operation prior to testing. The spalling allowed both penetrant and filtered particles to flow between the coating and base metal thus making this specimen undesirable for these tests.

Our plan is to stress the second specimen in small increments (ca. $200 \mathrm{lb}$ steps) after an initial load of $2500 \mathrm{lb}$ with filtered particle testing performed after each stress step.

We are also investigating the use of the electrified-particle testing method. The necessary equipment, i.e., spray gun and calcium carbonate powder, has been ordered.

\subsection{Iron and Nickel Carbonyl Formation and Prevention}

J. H. DeVan, H. Inouye, and J. Brynestad

Bell-shaped curves describe the generation rates of iron carbonyl versus temperature resulting from the reaction of carbon monoxide or the mixed gases with a $1 / 2 \%$ Mo-steel. Peak generation rates with carbon monoxide occur at about $200-220^{\circ} \mathrm{C}$ and with the mixed gases $\left(30 \mathrm{CH}_{4}-5 \mathrm{IH}_{2}-\right.$ $17 \mathrm{CO}-2 \mathrm{CO}_{2}$ in vol \%) at about $175^{\circ} \mathrm{C}$. At a $\mathrm{P}_{\mathrm{co}}$ of $170 \mathrm{psi}$ these curves intersect at $190^{\circ} \mathrm{C}$ from which it is noted that more iron carbonyl is generated below $190^{\circ} \mathrm{C}$ in the mixed gases than in carbon monoxide and vice-versa above this temperature. No further work is planned as this program has been cancelled.

\subsection{Development of Techniques for Welding and Cladding Cr-Mo and Low-Alloy Steels}

G. M. Best, D. P. Edmonds, and G. M. Goodwin

We are investigating methods for producing sound clad layers of Alloy 20 stainless steel on carbon and low-alloy steel substrates for coal. conversion applications. We are continuing to perform a literature 
review on various techniques for cladding with this material and problems encountered with these techniques. Most of the library research is complete and initial preparation of a report has begun. Also, we have obtained type 320 stainless steel (American Welding Society designation for Alloy 20, which is a Carpenter Technology designation) welding wire in $3.175 \mathrm{~mm}$ ( 0.125 in.) diam size for submerged-arc (SA) and gas metalarc (GMA) welding. We have made initial SA clad deposits on a carbonsteel substrate using this wire with two different sets of welding conditions. These deposits are presently being evaluated for microfissuring, under-bead cracking and effects of dilution.

\title{
3.5 Prestressed Concrete Pressure Vessel Studies
}

\author{
W. L. Greenstreet
}

The objective is to invectigate the potential use of prestressed cuncrete pressure vessels (PCPV) for coal conversion processes, to identify major problem areas, and to define and outline a test program (or programs) for feature and concept demonstration. Conceptual designs of pressure vessel and liner combinations for commercial size systems are to be developed and studied as vehicles for assessment and guidance.

During this month, the thermal analysis work on the hot-liner concept was completed, and local temperatures at anchor-to-liner attachments were calculated. Structural material selections were made and influences of process hydrogen on prestressing tendons were considered. The refractory studies were completed, and recommendations were made for insulation on the outside of the concrete vessel.

Under task 1, the conceptlial designs for both the Synthane and the HYGAS vessels were completed. Estimates of structural materials needed for the HYGAS vessel were prepared; these estimates for the Synthane vessel were quoted earlier.

Lower bound estimates were made for liner temperatures at the anchor attachment points. The square pitch spacing for anchors to support the liner was taken as $0.15 \mathrm{~m}$ ( 6 in.); the refractory anchors were also taken as being on the same pitch and located coincident with the liner support anchors. Alternate refractory support anchors are for the hard-face layer. For the combination of a long (hard-facing refractory) anchor and a liner support anchor, the liner ternperature in the vicinity of the dual attachment would be about $511 \mathrm{~K}\left(460^{\circ} \mathrm{F}\right)$. This is based on the simplifying assumption that the temperature of the portion of the linersupport anchor protruding into the structural concrete is held at the cooling-water temperature. For the case in which a liner anchor stud is not attached opposite to a refractory anchor stud but the remaining conditions are unchanged, the computed local temperature is reduced to about $478 \mathrm{~K}\left(400^{\circ} \mathrm{F}\right)$. Since these temperatures are lower than would be expected, local temperature variations should not impose undue problems. 
The liner material selected for the hot-liner concept is to conform to the requirements of $S A 387$, Grade 22 and is to be heat treated to produce a minimum yield strength of $379 \mathrm{MPa}(55 \mathrm{ksi})$. The thickness of the liner is to be $0.025 \mathrm{~m}$ ( 1 in.), which includes a corrosion allowance of $6.4 \times 10^{-3} \mathrm{~m}(0.25 \mathrm{in.})$ on the outer surface. The inside surface is to be covered by a $6.4 \times 10^{-3} \mathrm{~m}$ ( $0.25 \mathrm{in.}$ ) thickness of type 304 stainless steel roll-bonded cladding for protection from process corrosives.

Forgings to be used around openings in the vessel are to conform to the requirements of SA 336, Grade F22 steel. Protection from the process environment is to be provided by type 308 stainless steel weld overlay.

The liner material selected for the cold-liner concept is to conform to the requirements of SA 537, Class 1 , and is to be temperature to a yield strength of $379 \mathrm{MPa}(55 \mathrm{psi})$. The plate thickness is to be $0.02 \mathrm{~m}$ ( 0.75 in.); a $6.4 \times 10^{-3} \mathrm{~m}(0.025$ in.) thick roll-bonded cladding of type 304 stainless steel is to cover the inside surface.

In the cold-liner case, forgings around the openings are to conform to the requirements of SA 508, Class 1 steel. Protection from the process environment is to be provided by weld overlay of type 308 stainless steel.

The removable steel closure plugs for both hot- and cold-liner concepts are to be made of material conforming to the requirements of SA 336, Grade F22. Surfaces exposed to the process environment will be roll-bond clad with type 308 stainless steel.

In examining the possible effects of hydrogen on prestressing tendons, it was concluded that of the three basic types of embrittlement, that is, internal reversible, reartion, and environmental, only environmental embrittlement needs to be considered. Open literature information which specifically relates to the case under study was not found. Thus, the most direct method for assessing the effects is to conduct a limited number of tests in $\mathrm{H}_{2}$ environments that hracket the limits possible in a PCPV application.

In all cases considered, the outer surface of a vessel is to be insulated with a $0.25 \mathrm{~m}$ (10 in.) thickness of a cellular or foam glass insulation. This insulation is to be installed in blocks and held in place by stainless steel strappling. Weather protection for the insulation is to be provided by an asphaltic or a butyl-rubber-based coating; the latter is preferred.

Under task 6, a program for verification and feasibility demonstration is being defined. Four study areas to be addressed include:

(1) test demonstration of structural adequacy of the vessel and of gradual and predictable response to overpressure loading, (2) experimental examination of the top head closure design proposed and the hold-down arrangement, (3) liner and tendon material behavior investigations, and (4) model testing to examine performance of the liner and thermal barrier systems under projected thermal and mechanical loading conditions. 


\subsection{Fluidized Bed Combustion}

R. H. Cooper and J. H. DeVan

We established a sampling plan for the destructive evaluation of at least four of the 16 surveillance test tubes subjected to a $500 \mathrm{hr}$ exposure to the fluidized bed coal combustor at Fluidyne Corporation. In addition, standards are being fabricated for eddy current inspection of these 16 tubes. The final selection of the four tubes for destructive investigation is being delayed until ORNL receives a report from the Fluidyne Corporation documenting the run conditions of the fluidized bed during this $500 \mathrm{hr}$ exposure.

\subsection{Failure Analysis and Prevention}

R. T. King

3.7.1 MHD Combustor Tubing (R. H. Cooper)

A final report for unfailed surveillance combustor tubes removed from a PERC boiler operated for $1000 \mathrm{hr}$ on a No. 6 coal-oil slurry is in review.

3.7.2 Pressure Letdown Valve (D. P. Edmonds and D. A. Canonico)

A final report in TM-form for a failed pressure letdown valve is in press.

\subsubsection{Examination of Fluidized Bed lubing from MERC}

Initial metallographic examination of type 310 stainless steel 0.25 in. OD Schedule 40 tubing from a fluidized bed at Morgantown Energy Research Center was performed. 


\section{ALKALI METAL VAPOR TOPPING CYCLES}

R. S. Holcomb and G. Samuels

\subsection{Potassium Vapor Topping Cycle}

R. S. Holcomb, D. B. Lloyd, and R. H. Guymon

\subsubsection{Design}

The condenser housing air exhaust stack drawings were released, two of four sample box and piping drawings were released, and a third has been checked. Three vapor separator modification drawings are being checked. Work is in progress on the design of the condensate return piping. and the boller to sample box pipings.

The thermocouple location, routing and attachment drawings for the potasslum condenser and the argon separator were completed and released. The terminal box wiring detail for these thermocouples is nearing completion. Work is continuing on the drawing for the boiler drum resistance type level element.

The front layout and wiring details for three new instrument panels have been determined.

Design of the control interlock circuits, measuring signal circuits, and pneumatic circuit schematics is continuing. The instrument application diagram was completed and all instrument components have been identifled. A tabulation of these components is being made.

The mechanical assembly and component drawings were transmitted to the CPFF contractor during the past month. Work continues on the structural drawings for the support tower extension.

\subsubsection{Fabrication}

Work continued on fabrication of the potassium vapor condenser and the argon separator. The dished heads for the fill and drain tank were received from the vendor and work on the tank has been resumed. The fill and drain tank enclosure has been completed. Work has begun on the potassium sampler and the sampler enclosure. Modification of several existing instrument panels obtained from another project was begun.

The steam sampler was removed from the boiler drum and the vapor separator is being installed. 


\subsubsection{System Operation}

Tests using the steam sampler to determine the uniformity of heat distribution throughout the boiler were concluded in December.

The steam sampler consists of a mechanism for positioning a calorimeter alternately at the discharge of each of the boller tubes. A measured portion of the boller feed water is diverted to flow through the calorimeter. By measuring the cooling water flow rate and temperature change and the steam and condensate temperatures, it is possible to determine the relative power distribution throughout the boller.

Approximately half of the tubes were measured at burner powers of $2 \times 10^{6}$ and $2.8 \times 10^{6} \mathrm{Btu} / \mathrm{hr}$. At the lower power there was a significant variation in the heat removal from the tubes in the outer bank of tubes which Indicated that stable bolling had not been achieved in the niter bank. At the higher burner power the variation was substantially reduced. The maximum variation of $\pm 30 \%$ from the average ia rnnstiered to be acceptable.

Rust Engineering is to begin work on February 1, 1977. In order to meet this date, special effort will be directed toward installing the vapor separator as quickly as possible to allow completion of this part of the water test by February 1. Delay in receiving the heads for the potasstum fill and drain tank will prevent early installation of the tank as originally planned. It is not expected that this will delay the project allluugh lt w1ll require somewhat more work later on. Some of the drawings for the tower will not be ready unt1l January 7 . This represents a one-week delay in that part of the schedule. 


\subsection{Coal-Fired Alkali Metal}

G. Samuels

The cycle analysis of the topping (alkali metal) part of the system was completed during the month. The results of the analysis for turbine inlet temperatures from $1850^{\circ} \mathrm{R}\left(1028^{\circ} \mathrm{K}\right)$ to $2000^{\circ} \mathrm{R}\left(1111^{\circ} \mathrm{K}\right)$ and condenser temperatures from $1350^{\circ} \mathrm{R}\left(750^{\circ} \mathrm{K}\right)$ to $1550^{\circ} \mathrm{R}\left(861^{\circ} \mathrm{K}\right)$ are given in Table 4.1 for cesium and potassium. The number of turbine stages varles from 3 to 5 and the number of feed heaters used in the system was always 2 less than the number of turbine stages. In the analysis of these cases, it was assumed that $25 \%$ of the moisture present at each bleed point was removed and fed to the heaters. The turbine efficiency varied between 77 and $82 \%$ and the cycle efficiency varied between 77 and $80 \%$ of the Carnot efficiency. Table 4.1 also shows the ratio of the exit area of the turbine to that of the inlet.

Table 4.2 gives information on the turbine design used in the analysis. For all cases the turbine hub radius was fixed at $20 \mathrm{in}$. $(0.51 \mathrm{~m})$. The most interesting column is that showing the height of the first stage blade for a power output of $2 \mathrm{MW}$ for the stage. The blade heights are the same for a cesium unit operating at $1800 \mathrm{rpm}$ as for a potassium unit operating at $3600 \mathrm{rpm}$. This means that the centrifugal stress on the first stage rotor blade, which is proportional to the square of the speed, is four times as great for the potassium turbine as for the cesium unit. Furthermore, as can be seen from Table 4.1, the required flow area and thus the blade height increases much more rapidly for the potasslum unit than for the cesium unit with the last stage requiring about 1.5 times the area. As the centrifugal blade stress is directly proportional to the rotor annulus area, the centrifugal blade stress in the last stage rotor will be about six times greater for the potassium turbine.

These differences in stress have a significant effect on the blade and rotor creep rates and allowable operating temperatures. The relation hetween rreep rate, stress, and temperature is shown in the following equation:

$$
\varepsilon=A \sigma^{\mathrm{m}} \mathrm{e}^{-\mathrm{h} / \mathrm{kT}}
$$

where

$$
\begin{aligned}
& \varepsilon=\text { creep rate } \\
& \mathrm{A}=\text { constant } \\
& \sigma=\text { stress } \\
& \mathrm{m}=\text { constant } \\
& \mathrm{h}=\text { activation energy } \\
& \mathrm{k}=\text { Boltzmann's constant } \\
& \mathrm{T}=\text { absolute temperature }
\end{aligned}
$$


Table 4.1. Sumary of alkall metal cycle analysis

\begin{tabular}{|c|c|c|c|c|c|c|c|}
\hline $\begin{array}{c}\text { Turbine Inlet } \\
\text { Temperature } \\
{ }^{\circ} \mathrm{R}\end{array}$ & $\begin{array}{l}\text { Condenser } \\
\text { Temperature } \\
{ }^{\circ} \mathbf{R}\end{array}$ & $\begin{array}{l}\text { No. Jf Turbine } \\
\text { Stages }\end{array}$ & $\begin{array}{l}\text { No. of Foed } \\
\text { Heaters }\end{array}$ & $\begin{array}{c}\text { Cycle } \\
\text { Efficiency } \\
\%\end{array}$ & $\begin{array}{l}\text { \% of Carnot } \\
\text { Efficiency }\end{array}$ & $\begin{array}{c}\text { Ratio of } \\
\text { Turbine Exit } \\
\text { Area to Inlet } \\
\text { Area }\end{array}$ & $\begin{array}{c}\text { Turbine } \\
\text { Efficlency } \\
\%\end{array}$ \\
\hline \multicolumn{8}{|c|}{ Cestum } \\
\hline $\begin{array}{l}2000 \\
2000 \\
2000\end{array}$ & $\begin{array}{l}1350 \\
1450 \\
1550\end{array}$ & $\begin{array}{l}5 \\
4 \\
4\end{array}$ & $\begin{array}{l}3 \\
2 \\
2\end{array}$ & $\begin{array}{l}25.4 \\
21.3 \\
17.2\end{array}$ & $\begin{array}{l}78.1 \\
77.6 \\
76.6\end{array}$ & $\begin{array}{r}21.6 \\
11.1 \\
6.2\end{array}$ & $\begin{array}{l}78.8 \\
78.6 \\
80.7\end{array}$ \\
\hline $\begin{array}{l}1900 \\
1900 \\
1900\end{array}$ & $\begin{array}{l}1350 \\
1450 \\
1550\end{array}$ & $\begin{array}{l}5 \\
4 \\
3\end{array}$ & $\begin{array}{l}3 \\
2 \\
1\end{array}$ & $\begin{array}{l}22.9 \\
18.4 \\
14.2\end{array}$ & $\begin{array}{l}79.1 \\
77.8 \\
77.2\end{array}$ & $\begin{array}{r}15.5 \\
8.0 \\
4.6\end{array}$ & $\begin{array}{l}79.2 \\
79.7 \\
78.8\end{array}$ \\
\hline $\begin{array}{l}1850 \\
1350 \\
1850\end{array}$ & $\begin{array}{l}1350 \\
1450 \\
1550\end{array}$ & $\begin{array}{l}4 \\
4 \\
3\end{array}$ & $\begin{array}{l}2 \\
2 \\
1\end{array}$ & $\begin{array}{l}21.6 \\
17.8 \\
13.0\end{array}$ & $\begin{array}{l}79.9 \\
82.3 \\
80.1\end{array}$ & $\begin{array}{r}13.3 \\
6.7 \\
3.7\end{array}$ & $\begin{array}{l}77.9 \\
80.4 \\
81.9\end{array}$ \\
\hline \multicolumn{8}{|c|}{ Potassium } \\
\hline $\begin{array}{l}2000 \\
2000 \\
2000\end{array}$ & $\begin{array}{l}1350 \\
1450 \\
1550\end{array}$ & $\begin{array}{l}5 \\
5 \\
4\end{array}$ & $\begin{array}{l}3 \\
3 \\
2\end{array}$ & $\begin{array}{l}25.3 \\
21.8 \\
17.7\end{array}$ & $\begin{array}{l}77.8 \\
79.2 \\
78.6\end{array}$ & $\begin{array}{r}38.9 \\
17.4 \\
8.8\end{array}$ & $\begin{array}{l}77.3 \\
79.0 \\
78.9\end{array}$ \\
\hline $\begin{array}{l}1900 \\
1900 \\
1.900\end{array}$ & $\begin{array}{l}1350 \\
1450 \\
1550\end{array}$ & $\begin{array}{l}5 \\
4 \\
4\end{array}$ & $\begin{array}{l}3 \\
2 \\
2\end{array}$ & $\begin{array}{l}22.8 \\
18.5 \\
14.7\end{array}$ & $\begin{array}{l}78.9 \\
78.1 \\
80.0\end{array}$ & $\begin{array}{r}26.3 \\
11.9 \\
6.2\end{array}$ & $\begin{array}{l}78.7 \\
78.6 \\
80.6\end{array}$ \\
\hline $\begin{array}{l}1850 \\
1550 \\
1850\end{array}$ & $\begin{array}{l}1350 \\
1450 \\
1550\end{array}$ & $\begin{array}{l}5 \\
4 \\
3\end{array}$ & $\begin{array}{l}3 \\
2 \\
1\end{array}$ & $\begin{array}{l}21.6 \\
17.3 \\
12.9\end{array}$ & $\begin{array}{l}79.8 \\
79.9 \\
79.7\end{array}$ & $\begin{array}{r}21.3 \\
9.7 \\
4.9\end{array}$ & $\begin{array}{l}79.0 \\
79.5 \\
79.9\end{array}$ \\
\hline
\end{tabular}


Table 4.2. Summary of turbine design analysis

\begin{tabular}{|c|c|c|c|c|c|c|c|}
\hline $\begin{array}{l}\text { Working } \\
\text { Fluid }\end{array}$ & $\begin{array}{c}\text { Turbine Inlet } \\
\text { Temperature } \\
{ }^{\circ} \mathrm{R}\end{array}$ & $\begin{array}{l}\text { Condenser } \\
\text { Temperature } \\
{ }^{\circ} R\end{array}$ & $\begin{array}{l}\text { Turbine Hub } \\
\text { Radius } \\
\text { in. }\end{array}$ & $\begin{array}{l}\text { Turbine } \\
\text { Speed } \\
\text { rpm }\end{array}$ & $\begin{array}{c}\text { First Stage } \\
\text { Blade Height } \\
\text { For 2MW Output } \\
\text { in. }\end{array}$ & $\begin{array}{c}\text { Rotor Inlet } \\
\text { Temperature } \\
{ }^{\circ} \mathbf{R}\end{array}$ & $\begin{array}{c}\text { Inlet Nozzle } \\
\text { Mach No. }\end{array}$ \\
\hline $\mathrm{Cs}$ & 2000 & 1350 & 20 & 1800 & 3.8 & 1855 & .80 \\
\hline Cs & 1900 & 1450 & 20 & 1800 & 5.5 & 1780 & .77 \\
\hline Cs & 1850 & 1550 & 20 & 1800 & 7.0 & 1750 & .75 \\
\hline $\mathrm{K}$ & 2000 & 1350 & 20 & 3600 & 3.8 & 1850 & .86 \\
\hline $\mathrm{K}$ & 1900 & 1450 & 20 & 3600 & 5.5 & 1780 & .84 \\
\hline $\mathrm{K}$ & 1850 & 1550 & 20 & 3600 & 7.0 & 1740 & .83 \\
\hline
\end{tabular}


The value of $\mathrm{m}$ is in the range of 4 to 8 while the value of the activation energy is normally between 80,000 and 100,000 for materials of interest. For illustration purposes a value of $m=6$ and $h=80,000$ will be used. For these values, the creep rate for the first stage blades in the potassium unit is 4100 times that for the ceslum unit. If one were to try to offset this higher creep rate with a lower temperature, then the blade temperature would have to be reduced from about $1850^{\circ} \mathrm{R}\left(1028^{\circ} \mathrm{K}\right)$ to $1550^{\circ} \mathrm{R}\left(861^{\circ} \mathrm{K}\right)$. However, as the temperature is reduced, the flow area and thus the blade helght would increase and the required temperature reduction would be even greater.

For the cestum turbine the centrifugal stress at the root of the first stage blade is about 1200 psi $\left(8.3 \times 10^{6} \mathrm{~Pa}\right)$ per each megawat of power output for a blade with a constant cross sectional area. A tapered blade would reduce this stress by about one-third.

Data to be used in other parts of the system have been selected for the overall plant analysis. The steam pressure for the bottoming system will be about $2000 \mathrm{psi}\left(1.4 \times 10^{7} \mathrm{~Pa}\right)$. The overall efficiency that w111 be used for the steam system will be $42,40.5$, and $39 \%$ for steam temperatures of $1000^{\circ} \mathrm{F}\left(811^{\circ} \mathrm{K}\right), 900^{\circ} \mathrm{F}\left(756^{\circ} \mathrm{K}\right)$ and $800^{\circ} \mathrm{F}\left(700^{\circ} \mathrm{K}\right)$, respectively.

The coal to be used will be Illinols No. 6, the same as for the ECAS study, and the combustion air system w111 be designed for $15 \%$ excess a1r. Stack gas losses will be based on a stack temperature of $300^{\circ} \mathrm{F}\left(422^{\circ} \mathrm{K}\right)$. 


\section{CRITICAL COMPONENTS TEST FACILITY}

R. E. MacPherson

Reviews of the draft reports on CCTF and VTM feasibility, X-OE-25 "Feasibility Study for Critical Components Test Facility," and X-OE-26 "Feasibility Study for Coal Process Valve Testing," were completed and the reports are being prepared for reproduction.

A visit was made to Ingersol1-Rand, Princeton, New Jersey, to review with them our work on the CCTF, to establish their viewpoint on testing of components for coal conversion processes and facility requirements for such work, and to review their work on continuous coal feeder units for high pressure systems. A subsequent visit was made to Ralph M. Parsons, Pasadena, California, to review their coal conversion program and their views on the need and requirements for component testing.

An outline was prepared of the conceptual design report on nonsite spectfic modules for testing valves, solids feeders, slurry pumps, and hot gas cleanup equipment. The report is being prepared by ORNL for submission to ERDA-FE at the end of January 1977. Preparation of the ORNL sections is underway and Stearns-Rodgers is preparing conceptual designs and cost estimates for the specified modules. A group visited Stearns-Rodgers, Denver, Colorado, to review the status of their subcontract work. Preliminary flow diagrams were reviewed and decisions on concept, operating conditions, and work scheduling were made. A review of their final designs and cost estimates is scheduled for the third week in January 1977. 


\section{ENGINEERING STUDIES AND TECHNICAL SUPPORT}

\section{J. R. McWherter}

\subsection{Process Modellng Support}

R. Salmon, D. S. Joy, and D. Lister

Representatives of Purdue, Lehigh, and Oak Ridge National Laboratory attended the meeting of the advisory board for the MIT process modeling project in Cambridge on December 12 and 13, 1976. Plans for the MIT program were discussed. Coordination between the MIT and the PurdueLehigh-UKNL projects appears to be proceeding well and should he heneficlal to both.

A report documenting the economic evaluation computer program PRP is now about $80 \%$ complete and should be finished during January.

Work continued on the Pipe lost program. This will consist of two parts. One program will produce a scale drawing giving the user a plan view of the plant. Once a satisfactory layout has been established, a second program will calculate the piping requirements and costs.

The plant layout program is capable of plotting up to 20 pipelanes and 500 separate pieces of equipment. The pipelanes are represented by parallel lines but are required to be horizontal or vertical. Pipelanes may intersect or extend beyond the boundaries of the plant. The routing of process piping is specified in terms of equipment and pipelanes.

Various figures may be plotted to represent processing equipment. The baslc figures are circles, ellipses, rectangles, and octagons. Several of the basic figures can be automatically combined to produce a composite picture. For example, a tower and 1 ts base are represented by a circle within an octagon. A rectangle and portions of an ellipse are used to represent a heat exchanger. The user inputs a signal indicating the type of figure desired and sufficient information to locate the piece of equipment and give its size.

At this time we do not plan to show the individual pipes, since the computer logic required to produce a legible drawing for a large number of pipes would be very complicated. It is felt that the benefits derived from this would not be worth the time required. 


\title{
6.2 Process Research Digest
}

\author{
F. J. Endelman
}

In our November progress report we described the response from ERDA contractors to our requests for information on their projects to be reported upon in the first issue of the Digest. As a result of personal phone calls in early December, all have now responded.

In December work proceeded on the "Flash Hydropyrolysis of Coal" (Institute of Gas Technology, City University of New York, Brookhaven National Laboratory) and "Conversion of Methanol to High Octane Gasoline" (Mobil) articles. The latter has been subcontracted to a professional free lance technical writer. Work on the mechanical design of the Digest (e.g., cover, type style, etc.) is also underway. It is expected that drafts of these articles, as well as one or more prototype covers, will be available for review by early February.

Writing of the article on "Zinc Chloride Hydrocracking of Coal and Coal Extracts" (Conoco, Utah) will begin in January. It should be available for review in late February.

The first draft of the article on the IGT Riser Cracking of Coal project for the Process Research Digest has been completed. The article on the CFI Fast Reactions for Coal Conversion project is presently being written (S. P. Singh).

\subsection{Survey of Industrial Equipment Capabilities}

\subsubsection{Rotating Components (M. Siman-Tov, W. R. Williams, J. R. Horton, and W. F. Boudreau)}

As a part of the ORNL Coal Technology Program, there was a need to conduct a survey of the capability of the United States' industry to provide the equipment required for future demonstration and commercial coal conversion plants. We have been asked to take responsibility for that part of the program which deals with rotating equipment: compressors, turbine, expanders, and pumps. During December, two additional engineers joined the project. J. R. Horton of the ORNL Engineering Process Design Department will be responsible for preparing final equipment lists and determining manufacturers to be contacted for information on rotating equipment and will also assist in the analysis of data obtained during the survey. W. F. Boudreau of the ORGDP Process Engineering Group w111 provide in-house expertise on rotating equipment. On December 1, a visit was made to Ingersoll-Rand Research Incorporated in Princeton, New Jersey. The trip was initiated as a part of the ORNL study on the Coal Conversion Critical Components Test Facility. Discussions were centered on that project. Capabilities of existing equipment, including rotating equipment, and rccearch needs were considered. Ingersoll-Rand indicated their willingness to provide information related to this survey. W. F. Buudreau 
and M. Sivan-Tov met with T. K. Lau of ERDA-FE, Major Facllity Project Management Division, in mid-December to discuss the status of the project and the proposed work statement and schedule. The initial equipment lists have been compiled from the four processes (Syntho11, Coalcon, HYGAS, and Bi-Gas) which were chosen as a basis for this study. Operating characteristics tabulated on these 1 lsts will be expanded to provide a more complete description of each item of equipment before the final list is prepared. Potential operating ranges for some rotating equipment are tabulated in Table 6.1. These ranges do not necessarily apply simultaneously for one item nor do they completely cover all of the requirements of rotating coal conversion equipment.

Table 6.1. Potential nperating ranges for rotnting equipment

\begin{tabular}{|c|c|c|c|c|}
\hline & Cumpressors & $\begin{array}{l}\text { Liquid } \\
\text { pumps }\end{array}$ & $\begin{array}{l}\text { Slurry } \\
\text { pumps }\end{array}$ & $\begin{array}{c}\text { Power recovery } \\
\text { turbines }\end{array}$ \\
\hline $\begin{array}{l}\text { Flow rate, } \\
\text { maximum }\end{array}$ & $1.25 \times 10^{6}$ acfm & $50,000 \mathrm{gpm}$ & $20,000 \mathrm{gpm}$ & $25,0 \cap n$ gem \\
\hline $\begin{array}{l}\text { Temperature, } \\
{ }_{\mathrm{O}}\end{array}$ & $a m b-700$ & $a m b-700$ & $a m b-600$ & $a m b-300$ \\
\hline Pressure, psia & atm -4500 & atm -4500. & atm -4500 & $a t m-4000$ \\
\hline $\begin{array}{l}\text { Pressure rise, } \\
\text { psia }\end{array}$ & $<1-3500$ & 4000 & $<10-4300$ & \\
\hline $\begin{array}{l}\text { Pressure drop, } \\
\text { psla }\end{array}$ & & & & up to 4000 \\
\hline $\begin{array}{l}\text { Molecular } \\
\text { weight }\end{array}$ & $2.4-44.1$ & & & \\
\hline $\begin{array}{l}\text { 3pecific } \\
\text { gravity }\end{array}$ & & $0.7-1.2$ & $0.8-1.4$ & $\sim 1$ \\
\hline $\begin{array}{l}\text { Solids } \\
\text { content }\end{array}$ & up to $1 \mathrm{gr} / \mathrm{arf}$ & & $0-.60 \%$ & \\
\hline
\end{tabular}




\subsubsection{Survey of Industrial Coal Conversion Equipment: Valves (W. R. Williams)}

Five reports on liquefaction and gasification plants were examined for valve specifications: Syntholl, Coalcon, HYGAS, B1-Gas, and Hydrocarbonization. Four of the reports included very little information on valves; the Coalcon report included only a few rotary valves for handling solids (coal, char, etc.). Contact will be made with the companies issuing the above reports during January to determine what additional valve data are avallable.

\subsubsection{Hot Gas Cleanup Equipment Survey (M. S. Edwards)}

The open literature was surveyed to determine equipment vendors and developers in hot gas cleanup. Recent reports detailing the progress in hot gas cleanup were obtained and reviewed to determine the state-of-theart. Contacts were initlated with several organizations involved in developmental efforts to ascertain trends in equipment for hot gas cleanup. An AIChE short course in particulate control was attended, providing a fundamental perspective on the generic problem of particulate removal.

\subsubsection{Waste Heat Recovery Equipment and Processes (W. R. Gambi11).}

A two-day AIChE course on Fluid Bed Reactors was attended. Fluid beds represent a class of heat exchangers which will be explored for this study.

A scoping survey of the characteristics of batch checker-work and continuous Ljungstrom type heat regenerators was begun.

\subsection{Large Air Separation Plant Study \\ W. R. Gambill}

A letter summarizing the requirements was prepared and sent to our Purchasing Department for possible distribution to potential subcontractors. 


\title{
7. PROCESS AND PROGRAM ASSISTANCE
}

\author{
J. R. McWherter
}

Process and program analysis studies are being conducted for the ERDA Fossil Energy Office of Program Planning and Analysis. This effort includes research studies on most of the coal conversion and utilization processes. The program objective is to provide, on a consistent basis, technical and economic evaluations of competing processes and systems for coal conversion and utilization.

\subsection{Low-Btu Coal Gasification}

J. P. Belk, H. F. Hartman, and D. E. Reagan

Useful background Information was obtained by attending two events in Chicago. Energy and coal conversion subjects were discussed at the American Institute of Chemical Engineers (AIChE) National Meeting and included topics such as: ERDA's low-Btu gasification program; low-Btu gas as an industrial fuel; evaluation of technology for low-Btu gas from coal; utilization of low-Btu gas in power systems; coal gasification hardware; and other process equipment. An AIChE course, "Catalytic Processing in Fossil Fuel Conversion," featured subjects such as: coal characteristics; coal liquefaction; coal gasification; synthesis gas conversion; and process engineering considerations.

Work continued on collecting and summarizing technical and descriptive data for the Lurgi fixed bed dry ash process. This process is being used as an example of the type of data that could be provided, if available. Topics include: state of development, process description, coal feed requirements, operating conditions, product gas properties, by-products, utilities and labor requirements, thermal efficiency, capacity, and environmental considerations. Other topics such as economic comparisons and regional considerations (coal source, product end use) will be added as time and manpower permit. Work began to accumulate the limited technical data available for the British Gas Council slagging ash version of the Lurgi gasifier.

The 50 plus types of gasifier processes that were listed in an intilial survey are being screened. Detailed information will be summarized for about 10 to 20 processes in a data book along with the Lurgi examples previously mentioned. The screening method (to reduce the processes from 50 to about 15) will consider the following factors: (1) gasifier type (flxed bed, fluidized bed, entrained flow, molten bath); (2) degree of commercialization (present, emerging, future); (3) source of development funding (government, industry, combined); (4) available resources (personnel, time).

A preliminary outline of the low-Btu subprogram report was prepared. This outline and accompanying text will be discussed and modified as necessary to obtain the desired contents and format for the report. 


\subsection{Direct Combustion}

H. I. Bowers, E. C. Fox, and R. L. Sinard

Work continued this month on gathering information to assess the state of the art of the various coal combustion technologies. Contacts were made with EPA, EPRI, Argonne National Laboratory, and ABMA. Trips are planned in January to meet with EPA and EPRI to discuss their respective programs. ABMA has provided some data on industrial boiler sales.

On December 22, we transmitted to ERDA and FEA our comments on the Council of Economic Priorities' analysis of nuclear plant performance. We will next address the CEP analysis of coal plant performance.

\subsection{Advanced Power Conversion Systems \\ A. P. Fraas, ${ }^{\star}$ G. Samuels, M. E. Lackey, W. M. Wells, and S. Thompson*}

Most of the effort during the month was in collecting further information on the technical history and the funds spent in the development of the various advanced power systems. A draft of a report on coalfired gas turbines was prepared and is currently under review within ORNL.

\subsection{Liquefaction}

A subcontract was signed with the Ralph M. Parsons Company, Inc., to conduct the studies on liquefaction processes.

\subsection{In Situ Coal Gasification \\ W. C. Ulrich}

The survey of literature pertaining to in situ coal gasification continued; to date over 270 documents have been collected. In December, emphasis was placed on acquiring reports and papers describing Russian efforts and results.

Comments on the preliminary outline of an evaluation technique for determining the relative states of development of in situ process were received from Lawrence Livermore Laboratory and the Laramie Energy Research Center. The comments were generally favorable and will be extremely helpful in developing the technique to be used for evaluating the candidate processes.

\footnotetext{
${ }^{\star}$ Consultant.
} 
Work was initiated on compiling a list of reglonal favorite in situ processes from the four candidates under consideration. Fourteen "base cases" were assembled from which final choices will be made. These base cases include four main regions of the United States, six major coal provinces, three basic types of coal, and various combinations of thick, thin, shallow, deep, and steeply-dipping coal beds.

\subsection{Coal Beneficiation}

G. R. Peterson and Suman Singh

Equipment 1ists were completed for the 15,000 TPD mechantcal beneficiation capacity plants. Prosess operating labor and operating matcrials are being developed for these cleaning units.

The evaluation of the TRW process for the 1,500- and the 15,000-TPD product coal plants have been $90 \%$ completed.

Premises were discussed for the development of a common economic basis for the OPPA studies.

\subsection{Gas Cleanup Studies}

M. S. Edwards

A meeting was held with the investigators of advanced power systems to identify the specific need for gas cleanup information. It was decided that the most pressing concern involves particulate removal from pressurized fluid bed combustors operating above 5 atmospheres. At this pressure level, power recovery from flue gases appears necessary at temperatures close to the combustor exit temperature $\left(\sim 1700^{\circ} \mathrm{F}\right)$. Power recovery turbines at such high temperatures currently impose very stringent particulate removal requirements. Hot gas cleanup processes will be investigated to determine which are capable of meeting these criteria.

In the area of low-Btu gas cleanup, the data base compilation was completed. Processes for high- and low-temperature gas cleanup were categorized, and the evaluation of applicable processes was initiated. Contacts are underway with specific process vendors where the open literature is not sufficiently detailed to allow a reasonable assessment. 


\subsection{Coal Prices and Volumes and Transportation Costs \\ O. L. Culberson ${ }^{\star}$ and H. F. Soard}

A correlation has been developed for the mine-mouth costs of eastern U.S. coals as a function of higher heating value, sulfur content, ash content, and contract quantity. This correlation is regarded as tentative pending tests for consistency with a similar correlation to be developed for western U.S. coals. Data for the western coals are being complled.

No progress was made this month on the costs of transporting coal and coal conversion products.

\subsection{The Potential for Synthesis of Chemicals from Coal}

A subcontract was signed with Radian Corporation to evaluate the potential of the synthesis of chemicals from coal as an ERDA research program.

The first task, a survey of primary feedstocks for the chemical industry, was initiated.

\footnotetext{
* Consultant.
} 
8. FOSSIL ENERGY ENVIRONMENTAL PROJECT

C. R. Boston

\subsection{Program Plan}

The detailed program plan was finalized and delivered to Fossil Energy/Major Facility Project Management on December 8, 1976.

\subsection{Environmental Inclusions In RFPs}

Our first major deliverable, "Environmental Inclusions in Requests for Proposals," was also finalized and delivered to FE/MFPM on December 3, 1976. No further work on this draft document is anticlpated until comments are recelved from ERDA. In the meantime, however, MFPM plans to use this draft document in upcoming contracts for pipeline gas demonstration plants.

\subsection{Landf1ll Storage of Solid Wastes}

Subtasks 1 and 2 (literature search and outline preparation) were completed as scheduled, subtask 3 (iiterature acquisition) is virtually complete, and subtask 4 (document preparation) is fully in progress. To date, manpower has been expended as originally committed. However, although the total projected manpower commltment is unchanged; it will need to be redistributed among the subtasks to concentrate additional effort on document preparation. With the change, it is anticipated that all milestones can be achieved as planned.

\subsection{Environmental Mon1toring Handbook}

Approximately $0.5 \mathrm{MM}$ was put on this task during the reporting period. A meeting was held to formulate the scope of the handbook and a brief outine was distributed to form the initial basis for work. Time during the munch was spent expanding the outlines and collecting literature to use in preparing the handbook. Meetings of the handbook group will be held every two weeks following the regular biweekly Fossil Energy Environmental Project meetings.

\subsection{Programmatic EIS-Pipeline Gae}

Approximately $0.5 \mathrm{MM}$ was put on this task during the reporting period, mainly on startup subtasks. 


\section{COAL-FUELED MIUS}

R. S. Holcomb and W. R. Mixon

This profect for analysis, design, and demonstration of a concept utilizing a fluidized-bed coal combustion system as a heat source for a gas turbine generator suitable for applications in Modular Integrated Ut1lity Systems (MIUS) is carried out under the ORNL-HUD-MIUS Program within the Energy Division. Work is supported by the U.S. Department of Housing and Urban Development under HUD Interagency Agreement No. IAA-H-40-72 and by the Energy Research and Development Administration, Office of Fossil Energy (formerly Office of Coal Research, Department of the Interior), under ERDA Contract No. E(49-18)-1742. The project consists of four phases: I - Conceptual Preliminary Evaluation; II - Conceptual Design; III - Detalled Design and Construction; and IV - Shakedown, Performance, and Endurance Tests.

\subsection{Program Status}

Design work on the system remains halted pending dectsions on program definition and additional funding. A preliminary plan outlining a proposed test program was prepared and sent to ERDA-FE to provide information in support of the contract package for the contract review board.

\subsection{Coal Metering and Feed Eystems}

A total of $100 \mathrm{hr}$ running time has been accumulated on the coal feed system endurance test. Problems have been encountered that prevent fully automatic operation, so the system has been operated during the day and shut down overnight. The problems are connected with a slight imbalance in flow rate of coal between components in the system. Over a period of time, a surplus of coal is accumulated at one point in the closed system and a manual change in operating speed is required to correct the condition. A revision is being made in system piping that is expected to solve the problems and make it possible to achieve unattended operation.

\subsection{Supplemental Studies}

The Fluidyne report on corrosion test operations is expected to be submitted by the middle of January 1977. Examination of the corrosion specimens at ORNL is scheduled to begin early in January.

The report on heat transfer tests was completed and submitted for typing and internal review. 


\section{ANALYTICAL CHEMISTRY}

W. R. Laing

No report this month.

11. CHEMICAL RESFARCH

L. M. Ferris

This work is reported quarterly.

12. LIFE SCIENCES

C. W. Gehrs

This work is reported quarterly. 
ORNL / TM-5770

\section{INTERNAL DISTRIBUTION}

1. I. Auerbach

2. M. Bender

3. N. E. Bolton

4. C. R. Boston

5. R. E. Brooksbank

6. C. H. Brown

7. D. A. Canonico

8. J. A. Carter

9. B. R. Clark

10. H. D. Cochran, Jr.

11. E. Copenhaver

12. F. L. Culler

13. R. M. Davis

14. D. G. Doherty

15. M. S. Edwards

16. F. J. Endelman

17. J. L. Epler

18. G. G. Fee

19. D. E. Ferguson

20. L. M. Ferris

21. R. C. Forrester III

22. A. P. Fraas

23. W. Fulkerson

24. W. R. Gambil1

25. R. B. Gammage

26. D. A. Gardiner

27. C. W. Gehrs

28. J. B. Gibson

29. W. L. Greenstreet

30. M. R. Guerin

31. C. W. Hancher

32. L. A. Harris

33. S. F. Herbes

34. J. R. Hightower

35. S. G. Hildebrand

36. M. R. H111

37. R. S. Holcomb

38. J. M. Holmes

39. J. K. Huffstetler

40. C. I. Hunt

41. G. R. Jasny, $Y-12$

42. R. L. Jolley

43. J. E. Jones

44. D. S. Joy

45. 0. L. Keller

46. R. T. King

47. W. R. Laing

48. R. S. Livingston

49. R. E. MacPherson
50. A. P. Malinauskas

51. G. B. Marrow

52. C. J. Mchargue

53. L. E. McNeese

54. J. R. McWherter

55. H. J. Metz

56-58. W. R. Mixon

59. J. E. Mrochek

60. P. Nettesheim

61-66. J. P. Nichols

67. L. C. Oakes

68. G. R. Peterson, Y-12

69-70. T. W. Picke1

71. W. W. Pitt

72. H. Postma

73. D. E. Reichle

74. C. R. Richmond

75. B. R. Rodgers

76. M. W. Rosentha1

77. T. H. Row

78. W. L. Russe11

79. Royes Salmon

80. C. D. Scott

81. D. S. Shriner

82. W. D. Shults

83. S. P. N. Singh

84. C. B. Smith

85. G. P. Smith

86. I. Splewak

87. R. L. Spore

88. E. G. St. Cla1r

89. J. B. Storer

90. R. A. Strehlow

91. O. K. Tallent

92. A. J. Thompson

93. D. B. Trauger

94. W. C. Ulrich

95. P. R. Vanstrum

96. J. S. Watson

97. J. R. Weir

98. P. R. Westmoreland

99. M. K. Wilkineon

100. L. V. Wilson

101. R. G. Wymer

102. C. S. Yust

103. Patent Office

104. Lab. Records

105-111. Lab. Records

112-114. Central Research L1brary

115. Document Reference Section 
EXTERNAL DISTRIBUTION.

ERDA, Oak Ridge Operations

116. Research and Technical Support Division

ERDA, Washington

117. W. Bakker, FER

118. N. F. Barr, DTO

136. L. Kindley, FER

119. J. D. Batchelor, CCU

137. C. Knudsen, FE/OPPA

120. R. Beck, CCU

138. T. K. Lau, MFPM

121. T. Beresovski, RD\&D

139. R. W. A. LeGassie, APA

122. L. M. Burman, OGST

123. E. L. Clark, CCU

124. N. P. Cochran, MFPM

140. J. L. Liverman, AES

125. T. Cux, FER

126. P. Duhame1, FEK

127. J. Forst, FER

128. H. Frankel, FER

129. S. I. Freedman, CCU

141. W. G. McDanie1, MFPM

130. D. Garrett, MFPM

131. S. W. Gouye, AFE

132. W. S. Harmon, MFPM

112-117. C. Miller, CCU

148. G. A. Mills, FER

149. W. E. Mott, DBER

150. M. B. Neuworth, CCU

151. E. S. Pierce, DPR

152. H. E. Podal1, MFPM

153. J. L. Powe11, MFPM

154. J. W. Ramsey, OGST

155. M. Reilly, FE/OPPA

156. John Shen, FER

133. R. M. Jimeson, DTO

157. A. P. Sikri, OGST.

134. H. R. Johnson, FE/OPPA

158. D. K. Stevens, DPR

135. H. Jones, MFPM

159. J. W. Watkins, OGST

160. P. C. White, AFE

161. P. R. Wieber, OGST

162. $R, W$, Wond, DBER

Department of Housing and Urban Development, 4517 th Street, S.W., Washington, DC 20410

163. G. S. Leighton

164. J. H. Rothenberg

National Science Foundation, 1800 G Street, N.W., Washington, DC 20550

165. R. S. Goor

166. Robert Rabin

University of Kentucky, Institute for Mining and Materials Research, 213 Bradley Hall, Lexington, KY 40506

167. Theresa Wiley, Institute Librarian

168. 0. J. Haun

169. J. K. Shau

170. Robert Rea, Resource Planning Associates, Inc., 44 Brattle St., Cambridge, MA 02138

171. William E. Pepelko, U.S. Environmental Protection Agency, ETRL, 1.055 Laidlow, Cincinnati, OH 45237

172. Charles B. Sedman, U.S. Environmental Protection Agency, Research Triangle Park, NC 27711

173. N. S. Boodman, Section Supervisor, U.S. Steel Corporation Applied Research Laboratory, 125 Jamison Lane, Monroeville, PA 15146 
174-185. ERDA Pittsburgh Energy Research Center, U.S. Energy Research and Development Administration, Attention: Director for J. P. Barreca, 4800 Forbes Ave., Pittsburgh, PA 15213

186-191. The D1rector, Morgantown Energy Research Center, P.0. Box 800, Morgantown, WV 26506

192. Tetra Tech, Inc., 1911 N. Ft. Myer Drive, Sulte 601, Arlington, VA 22209, Attention: Walter McGough, Jr.

193. Cameron Engineers, Attn: Gary L. Baughman, 1315 South Clarkson St., Denver, CO 80213

194-220. Technical Information Center, ERDA 